\title{
Investigating design and technology students' participation and learning in a technology mediated learning environment
}

Tiong Meng Yeo

Marsiling Secondary School, Singapore

Choon Lang Quek

Nanyang Technological University, Singapore

This study investigates how 15 Design \& Technology (D\&T) students (aged 15 years) participated in three stages of the design process in a technology mediated environment. The three stages are named Situation, Ideation and Development. The learning process is mediated by Knowledge Forum (KF), an asynchronous online discussion tool. The students' online messages and participation were analysed qualitatively and quantitatively using a self developed coding scheme. Findings showed that discussions among students were not evident in the Situation stage but were evident in the Ideation and Development stages. Participation levels from one of the three groups of students in the three design stages were very different from the other two groups. Generally, a relatively high level of in depth information processing as compared to surface level of information processing was observed in the three design stages.

\section{Introduction}

Technology plays an increasingly important role in education. It has, among its benefits, the value of making the knowledge construction process explicit, thereby helping learners to become aware of that process (Brown \& Campione, 1996). It serves as a mediation tool or agent facilitating the learning process. Much of the research on mediation tools like text based online communication has involved asynchronous media such as discussion forums and bulletin boards (Dabbagh \& Bannan-Ritland, 2004). The participants in asynchronous online discussions have more flexibility, can draw on more resources for composing responses, and have the time to reflect on their messages (Jonassen \& Kwon, 2001; Ng \& Cheung, 2007).

Discussion through interaction among students and between students and instructor is the key to the learning and collaboration that result from it (Palloff \& Pratt, 1999). Aside from augmenting the instructor's feedback, discussion with peer feedback will enable students to grow and learn from each other, scaffolding their current knowledge and perspectives from one another, co-constructing ideas and knowledge (Roehler \& Cantlon, 1997). The social and cognitive processes involved in online interaction are significant in creating a community of learners (Wenger, 1998) and are considered as a positive use of the social constructivist approach to learning (Bonk \& Cunningham, 1998; Palloff \& Pratt, 2005). 
A project based, learner centred approach is adopted in D\&T where students work collaboratively in small groups, and knowledge is built from the creation and improvement of design ideas. There are four stages of the design process that they are expected to experience in their learning activities, named Situation, Ideation, Development and Realisation. At Situation, they are expected, from a design situation that describes a design issue, to better understand the requirements of the design task, focusing on the context and the needs, problems, desires or wants that require solutions. At Ideation, they are encouraged to be creative and open minded, generating and evaluating design ideas which lead to a final one to be chosen. At Development, they work on the details of their chosen ideas such as choice of materials and technology. At Realisation, students make the product. A component named Research is on going throughout the process and it involves gathering information for decision making purposes. However, for this study, online discussion involves only the stages of Situation, Ideation and Development.

When students share ideas in a discussion, the feedback they receive from classmates will often cause cognitive dissonance because it conflicts with their original views. The dissonance encourages students to revise their views and test their revised views in light of further peer review among the class (Knowlton, Knowlton, \& Davis, 2000). The mediation of technology in this context involves technology acting as intermediary agent in effecting communication among learners in an online environment. In such an environment, teachers play major roles in designing the educational experience, facilitating the learning and providing direct instruction (Anderson, Rourke, Garrison \& Archer, 2001; Jamaludin \& Quek, 2006).

In Hong Kong, the Design and Applied Technology (DAT) syllabus states its design process as identification of a design need, statement on design tasks, acquisition of the necessary skills, modelling and fabrication of a prototype, and assessment of the feasibility, implementation and value of the design. The D\&T syllabus in England requires students to identify a need or design opportunity, generate design proposals that are modified through evaluation, and making the proposed solution. In the Australian syllabus, students undertake a major design project which involves the steps of project proposal and management, project development and realisation, and evaluation. Generally, all the syllabi have similarity in that the steps in the design task involve identification of need, generation of ideas, development of ideas and making of prototype or product.

Participation in discussion forums provides opportunities for responsible and active learning (Hopperton, 1998). Participants in virtual conferences construct knowledge through the shared experiences that each brings to the collaborative discussions. This is an example of using technology as a cognitive tool which stimulates cognitive learning strategies and critical thinking (Jonassen, 1998). Effective participation occurs where communication facilitates the development of a deep understanding of the material through sharing and critically evaluating ideas, and where connections are made between elements of the learning material (Klemm \& Snell, 1996).

Learning has been regarded as a cognitive activity by a large number of renowned researchers, including Piaget (1970) and Vygotsky (1962), whose approach to learning focused on what went on in the learner's head. In the context of D\&T, discussion among the participants requires them to recall from memory information that they may have acquired previously. It also requires them to reason as they analyse, evaluate and suggest improvements to ideas presented in the online forums. All of these 
involve cognition. It is difficult to regard the learning process as distinct from cognitive processing, a view shared by researchers such as Jonassen (1991), van Jooligan (1999) and Albacete and VanLehn (2000a, 2000b).

Analysis of online learning usually involves evaluation of the cognitive aspect of learning. Henri (1992), for example, developed an analytical model that highlights five dimensions of the learning process that can be found in messages. One of the five dimensions is the cognitive dimension which measures reasoning and critical thought. To further understand the presence and frequency of certain cognitive skills, Henri's model also identified the level of information processing as surface or in depth processing, as adopted from Entwistle and Waterston (1988). According to Henri (1992), surface level processing includes such factors as making judgments without justification, stating that one shares ideas or opinions already stated, and asking irrelevant questions. In contrast, in depth processing is apparent when one links facts and ideas, discusses advantages and disadvantages of a situation, and makes judgments that are supported by examples and/or justification.

With the mediation of technology which makes D\&T learning explicit in the environment, this study explores how the learning process takes place and the cognition that results from participation in the discussion. The research questions that have been formulated were:

1. How do student groups

(a) represent the design situation?

(b) generate design ideas?

(c) develop ideas?

2. How do different groups of students learn through their online participation across the D\&T design stages?

\section{Methodology}

\section{Sample}

The sample consisted of 15 D\&T students (aged 15) from a high school. There were six girls and nine boys. The students were regarded as having slightly above average ability. All had access to computers at home, and in school, computers in the laboratories were available to them in and after curriculum time. They had no prior experience in asynchronous online discussion and were participating in it for the first time. The online forum started on 4 March and ended on 11 August 2007. During this period, there were term breaks from 11 to 17 March, and 27 May to 23 June. There were also periods of time when there was no forum discussion due to the school's continual assessments and semester examinations. A total of 5 weeks were spent on this technology mediated learning environment.

\section{Procedure}

Student induction

A short lesson was conducted to familiarise students with Knowledge Forum (KF), an asynchronous online discussion tool, after which they were given practice time to become comfortable and proficient with the software. Students were told the purpose of the online discussion, which was mainly sharing each participant's views and opinions about the discussion ideas, exhibiting thinking ability and gaining a deeper 
understanding in the process. They were also made aware that the asynchronous mode allowed them to participate in the discussion at any time and place. They were encouraged to participate actively.

Ground rules

Students were first instructed to access the note entitled "Ground rules" in order to be aware of the goal of the discussion and what they were supposed to do. The ground rules included instructions that they were to:

1. Respect each other's views and exercise courtesy when expressing one's own views.

2. Participate actively for quantity and quality in the discussion.

3. Keep content of postings related to the discussion topic.

Warm up activity

As a warm up activity, students were given a simple discussion topic to encourage social communication. The given topic was about the use of public toilets in Houston. A short period of time (about 30 minutes) was given to them for this activity.

\section{DET learning activities}

Students were assigned randomly to three groups of five. Members in each group worked collaboratively to make group decisions and advance progressively into final completion of the product. Face to face discussions took place between the members in each group and online discussions involved every participant in the class.

In this study, students were given a situation which was about carrying cups in one hand. Discussion at this stage was focused on identifying and having a better understanding of the design task and its context. User needs that were identified, design factors that were considered, and any other relevant research data were posted onto the forum. Every student then generated and contributed to the forum possible solutions to the design task in the form of design ideas, and this was the ideation stage. These ideas were discussed and critiqued by every participant in the online environment, and refinements and improvements were progressively made to the ideas. Next, members in each group met face to face to select a final design idea for them to work on. The chosen design idea was then developed, and all necessary details needed for fabricating the idea were considered.

The use of KF complemented face to face meetings. The students were engaged in individual and group activities including identification and representation of design situation, generation and evaluation of design solutions, selection of a final design idea, development of solution details, evaluation of those details and research findings and sharing. The teacher participated by structuring the activities, monitoring the discussions and making timely postings to encourage student participation and guide discussion of controversial points, encouraging depth of thinking and verifying the quality of resources used.

\section{Survey}

A simple survey was administered to the students to assess their perception of online discussions in terms of learning, motivation and enjoyment. The survey included statements such as "Online discussion provides useful social information" and "Online discussion makes me more interested in the subject". The students responded by 
answering "Agree", "Disagree" or "Not sure". There were nine statements for learning from online discussions and eight for motivation and enjoyment (see Appendix 1).

\section{Coding scheme for this study}

Figure 1 shows the D\&T design process. The Designing domain comprises Situation, Ideation and Development. Realisation belongs to the Making domain. Table 1 shows the coding scheme used to analyse D\&T design process in this technology-mediated environment. It focuses on the Designing domain of the D\&T curriculum and is based on the conceptual framework of the design process in Figure 1.

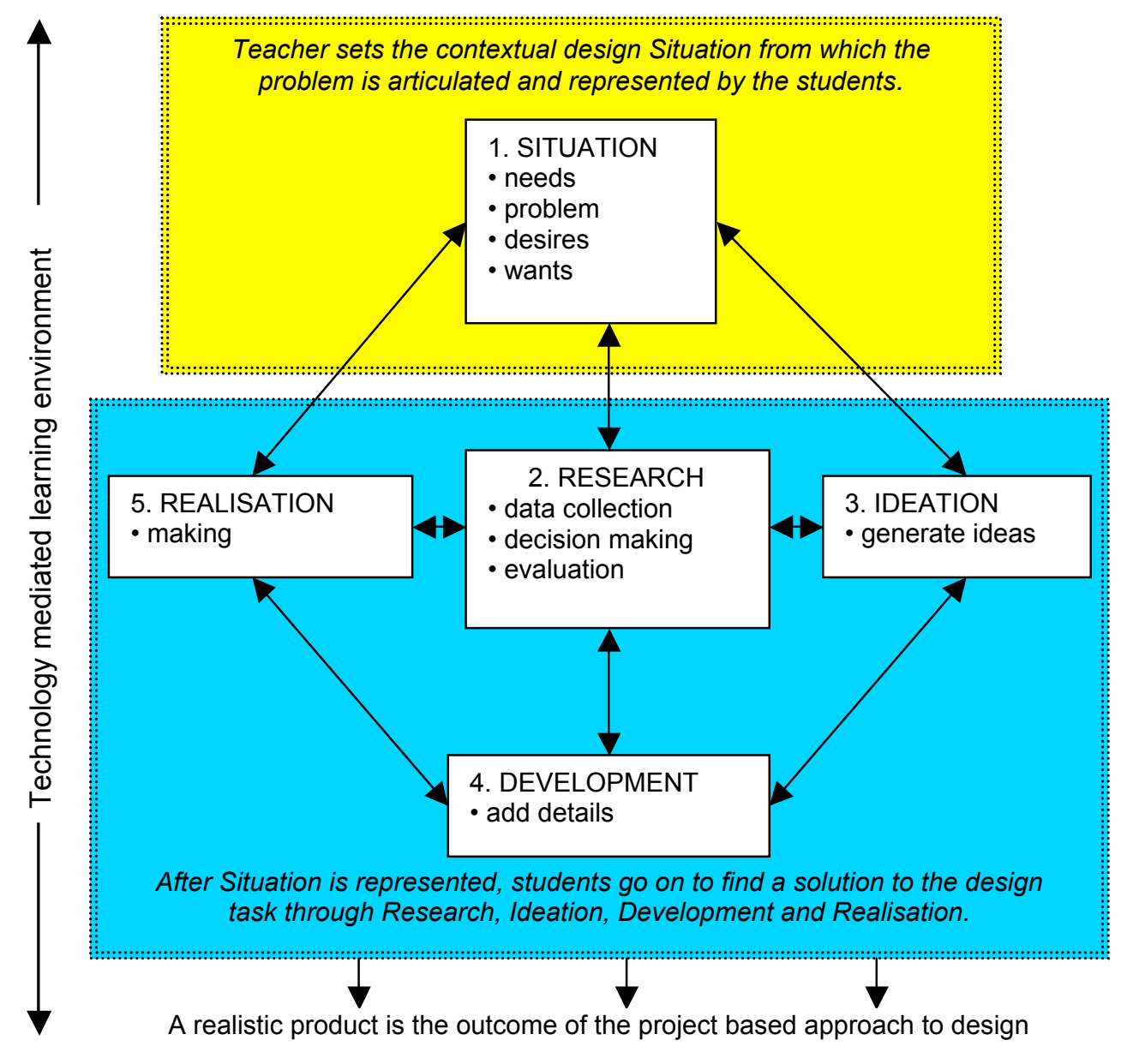

Figure 1: Design process

Source: Adapted from D\&T Syllabus (2006)

The stages of Situation, Ideation and Development in the design process that would be evident as message postings in the online forum in this study are collected. These stages provide a structure for the identification and measurement of D\&T design process in an asynchronous online learning environment. 
Table 1: Coding scheme

\begin{tabular}{|c|c|c|c|}
\hline $\begin{array}{l}\text { Design } \\
\text { stage }\end{array}$ & Indicators & $\begin{array}{c}\text { Individual/ } \\
\text { peer } \\
\text { contribution }\end{array}$ & $\begin{array}{l}\text { Learning } \\
\text { tasks }\end{array}$ \\
\hline Situation & $\begin{array}{l}\text { - Students consider needs and values of } \\
\text { intended users } \\
\text { - Students consider following factors that } \\
\text { affect design: } \\
\text { 1. Users } \\
\text { 2. Function } \\
\text { 3. Aesthetics } \\
\text { 4. Materials } \\
\text { 5. Cost } \\
\text { - Students gather relevant information to } \\
\text { consider following factors that affect design: } \\
\text { 6. Users } \\
\text { 7. Function } \\
\text { 8. Aesthetics } \\
\text { 9. Materials } \\
\text { 10. Cost }\end{array}$ & I & 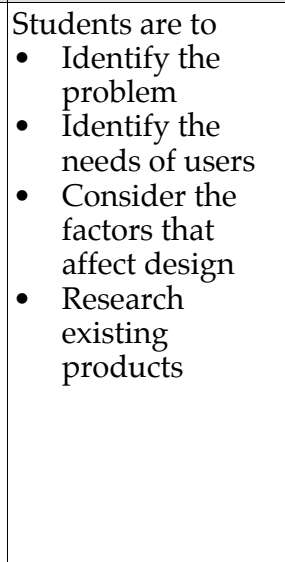 \\
\hline Ideation & $\begin{array}{l}\text { - Students use the following ideation } \\
\text { techniques to generate or improve ideas: } \\
\text { 1. Triggers for idea } \\
\text { 2. SCAMPER } \\
\text { 3. No evidence of technique } \\
\text { - Students use the following scaffolds to } \\
\text { communicate: } \\
\text { 1. Agree with idea/s } \\
\text { 2. Critique idea/s } \\
\text { 3. Suggest improvement/s } \\
\text { 4. Critique idea/s and suggest } \\
\text { 5. Acknowledge comment/s } \\
\text { 6. Seek clarity } \\
\text { 7. Defend idea/s } \\
\text { - Students improve on previous idea }\end{array}$ & $\mathrm{P}$ & 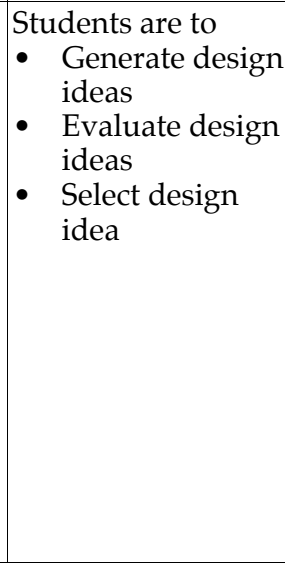 \\
\hline Development & $\begin{array}{l}\text { Develop ideas by considering following } \\
\text { design factors: } \\
\text { 1. Users } \\
\text { 2. Function } \\
\text { 3. Aesthetics } \\
\text { 4. Materials } \\
\text { 5. Cost } \\
\text { - Students use the following scaffolds to } \\
\text { communicate: } \\
\text { 1. Agree with idea/s } \\
\text { 2. Critique idea/s } \\
\text { 3. Suggest improvement/s } \\
\text { 4. Critique idea/s and suggest } \\
\text { 5. Acknowement/s } \\
\text { 6. Seek clarity } \\
\text { 7. Defend idea/s } \\
\text { Students improve on previous idea }\end{array}$ & $\mathrm{P}$ & 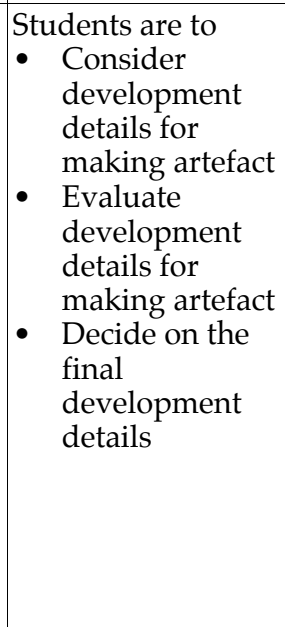 \\
\hline
\end{tabular}




\section{Analysis of discussion data transcripts}

A content analysis approach based on the coding scheme was adopted for analysis of the data transcripts. Students' cognitive processes in the discussion forums were analysed using Henri's (1992) levels of information processing of cognitive dialogue in the asynchronous online discussion environment. Cognitive dialogue refers to texts located within the postings of an asynchronous discussion forum that are indicative of learners' cognitive skills and strategies while engaged in a learning process (Henri, 1992; Henri \& Rigault, 1996), such as analysing, inferencing, judging, and synthesising.

\section{Quantitative analysis of student participation}

Students' participation levels in the discussion forum were analysed quantitatively. The definition of participation level in this study is the number of student posted messages in the stages of the design process in the discussion forum. The online discussion forum allowed students to work together on projects in small groups, participate in on going discussions focused on design and make activities, and to make and present group projects in the form of artefacts to the rest of the class. All of this was carried out independent of student location and time of actual participation in the discussion forum, and was coordinated with structured instructions in the course of the activities.

\section{Findings and discussion}

Research question 1(a): How do student groups represent the design situation?

Coding was carried out by the researcher with a D\&T teacher as the second coder. An intercoder agreement of $92 \%$ was established. The representation of the design situation occurred at the Situation stage of the design process. A total of 29 messages were posted, out of which 4 messages were posted by the teacher and 2 messages were irrelevant. The remaining 23 messages were posted by the students. Coding results of the 23 relevant messages posted by the 15 participating students at the Situation stage are shown in Table 2.

Table 2: Coding result for representation of design situation

\begin{tabular}{|c|c|c|}
\hline $\begin{array}{l}\text { Design } \\
\text { stage }\end{array}$ & Indicators & $\begin{array}{l}\text { No. of student } \\
\text { messages }(\%)\end{array}$ \\
\hline \multirow[t]{2}{*}{ Situation } & $\begin{array}{l}\text { - Students consider needs and values of intended users } \\
\text { - Students consider design factors that affect design } \\
\text { - Students gather relevant information to consider design } \\
\text { factors that affect design }\end{array}$ & $\begin{array}{c}11(47.8) \\
1(4.4) \\
11(47.8)\end{array}$ \\
\hline & & $23(100)$ \\
\hline
\end{tabular}

At the Situation stage, contributions to the forum were noted to be individual with each student expressing their own representation about the design situation. The teacher first posted his message describing the design situation, and the students' messages were posted in response to the teacher's posting. $11(47.8 \%)$ messages out of the total of 23 messages at this stage were analysed as identification of user needs. When considering factors that might affect design, it would be logical to research existing products in order to have an idea how the various design factors could come into play. However, there was a message that considered the factors without any prior research. This student could have forgotten to attach the research material, or simply 
did not see the need to conduct the research. $11(47.8 \%)$ messages out of the 23 messages have considered the design factors with prior research on existing products. Research at this stage is important as it is to help students to generate ideas in the next stage of the design process which is the Ideation stage.

Research question 1(b): How do student groups generate design ideas?

The generation of design ideas occurred at the Ideation stage of the design process. A total of 74 messages were posted, of which 12 messages were posted by the teacher and 5 were irrelevant. The remaining 57 messages were posted by the students. Coding results of the 57 messages posted by the 15 students at the Ideation stage are shown in Table 3.

Table 3: Coding results for generation of design ideas

\begin{tabular}{|c|c|c|}
\hline $\begin{array}{l}\text { Design } \\
\text { stage }\end{array}$ & Indicators & $\begin{array}{l}\text { No. of student } \\
\text { messages }(\%)\end{array}$ \\
\hline \multirow[t]{4}{*}{ Ideation } & $\begin{array}{l}\text { - Students use the following ideation techniques to generate ideas: } \\
\text { 1. Triggers for idea } \\
\text { 2. SCAMPER } \\
\text { 3. No evidence of technique }\end{array}$ & $\begin{array}{c}7(12.3 \%) \\
0 \\
6 \\
1\end{array}$ \\
\hline & $\begin{array}{l}\text { Students use the following scaffolds to communicate: } \\
\text { 1. Agree with idea/s } \\
\text { 2. Critique idea/s } \\
\text { 3. Suggest improvement/s } \\
\text { 4. Critique idea/s and suggest improvement/s } \\
\text { 5. Acknowledge comment/s } \\
\text { 6. Seek clarity } \\
\text { 7. Defend idea/s }\end{array}$ & $\begin{array}{c}46(80.7 \%) \\
1 \\
6 \\
17 \\
15 \\
1 \\
5 \\
1\end{array}$ \\
\hline & - Students improve on previous idea & $4(7 \%)$ \\
\hline & Total & $57(100 \%)$ \\
\hline
\end{tabular}

No design idea was generated using the Triggers technique and one design idea was generated without evidence of any technique used. The Triggers technique involves students using objects or pictures as idea triggers. The students might have found the Triggers technique difficult to use as compared to SCAMPER which is also an idea generating technique. SCAMPER is an acronym for Substitute, Combine, Adapt, Modify, Put to other uses, Eliminate and Reverse. Generating design ideas without any technique is not recommended for students as it does not make their thinking visible. Table 3 shows that a total of $46(80.7 \%)$ messages were scaffolds that students have used to help others improve on their design ideas. Most of these scaffolds, 17 of them, were suggestions to help others improve on their design ideas. The aim of the technology mediated environment in this study is to enable improvements of ideas to be made through collaboration and interaction among the students. The coding results in Table 3 show a total of four improvements made to the generated design ideas through discussions.

Research question 1(c): How do student groups develop ideas?

The development of chosen design ideas occurred at the Development stage of the design process. There were 41 messages posted, with 3 messages by the teacher and 1 irrelevant message. Coding results of the 37 messages posted by the 15 students at the Development stage are shown in Table 4. 
Table 4: Coding results for development of ideas

\begin{tabular}{|c|c|c|}
\hline $\begin{array}{l}\text { Design } \\
\text { stage }\end{array}$ & Indicators & $\begin{array}{c}\text { No. of student } \\
\text { messages }(\%)\end{array}$ \\
\hline \multirow[t]{11}{*}{ Development } & - Develop ideas by considering design factors & $19(51.4)$ \\
\hline & - Students use the following scaffolds to communicate: & $15(40.5)$ \\
\hline & 1. Agree with idea/s & 2 \\
\hline & 2. Critique idea /s & 4 \\
\hline & 3. Suggest improvement/s & 1 \\
\hline & 4. Critique idea/s and suggest improvement $/ \mathrm{s}$ & 2 \\
\hline & 5. Acknowledge comment/s & 0 \\
\hline & 6. Seek clarity & 4 \\
\hline & 7. Defend idea/s & 2 \\
\hline & - Students improve on previous idea & $3(8.1 \%)$ \\
\hline & & $37(100)$ \\
\hline
\end{tabular}

At the Development stage, $19(51.4 \%)$ messages were coded as consideration of design factors. The high participation observed at this point could be due to the simple designs in the teacher's design task that was presented to the students. The task was framed in such a way that it did not require students to tackle more complex issues and to consider other design factors. There were $15(40.5 \%)$ messages coded as scaffolds for helping others improve on their development ideas. This number was low in comparison with the scaffolds in Ideation where there were 46 messages. This implies that the discussion towards the improvement of ideas in Development was not as vigorous as in Ideation. This could be due to the relative simplicity in the product design ideas, which did not require much development detail.

Research question 2: How do different groups of students learn through their online participation across the D\&T design stages?

\section{Group participation at each design stage}

The quantitative measures of the overall participation level by each of the three project groups at each stage of the design process are summarised in Table 5. Participation level was based on the number of student posted messages by each project group. Each project group comprised 5 members. The graphical representation of the group participation level of each project group at each stage of the design process is shown in Figure 2.

Table 5: Group participation level at each design stage (No. of students $=15)$

\begin{tabular}{|c|c|c|c|}
\hline \multirow{2}{*}{ Group } & \multicolumn{3}{|c|}{ No. of Messages (\%) } \\
\cline { 2 - 4 } & Situation & Ideation & Development \\
\hline 1 & $9(7.7)$ & $24(20.6)$ & $12(10.3)$ \\
\hline 2 & $8(6.8)$ & $27(23)$ & $13(11.1)$ \\
\hline 3 & $6(5.1)$ & $6(5.1)$ & $12(10.3)$ \\
\hline Overall & $23(19.6)$ & $57(48.7)$ & $37(31.7)$ \\
\hline
\end{tabular}

All the three groups started with low participation levels at Situation. At Ideation, groups 1 and 2 increased their participation levels whereas group 3 remained at the same level of participation as at Situation. At Development, participation levels of groups 1 and 2 decreased while that of group 3 increased.

At the Situation stage, students could be new to the online environment and therefore not feeling comfortable participating in the forum. The design situation given to the 
students at this stage could also contribute to the low participation. The design situation might be too simple and direct so that it did not need any discussion from the students to understand it. In fact, the messages posted by the students at this stage were mainly in direct response to the teacher's posting of the design situation. There was no interaction among the students at this stage.

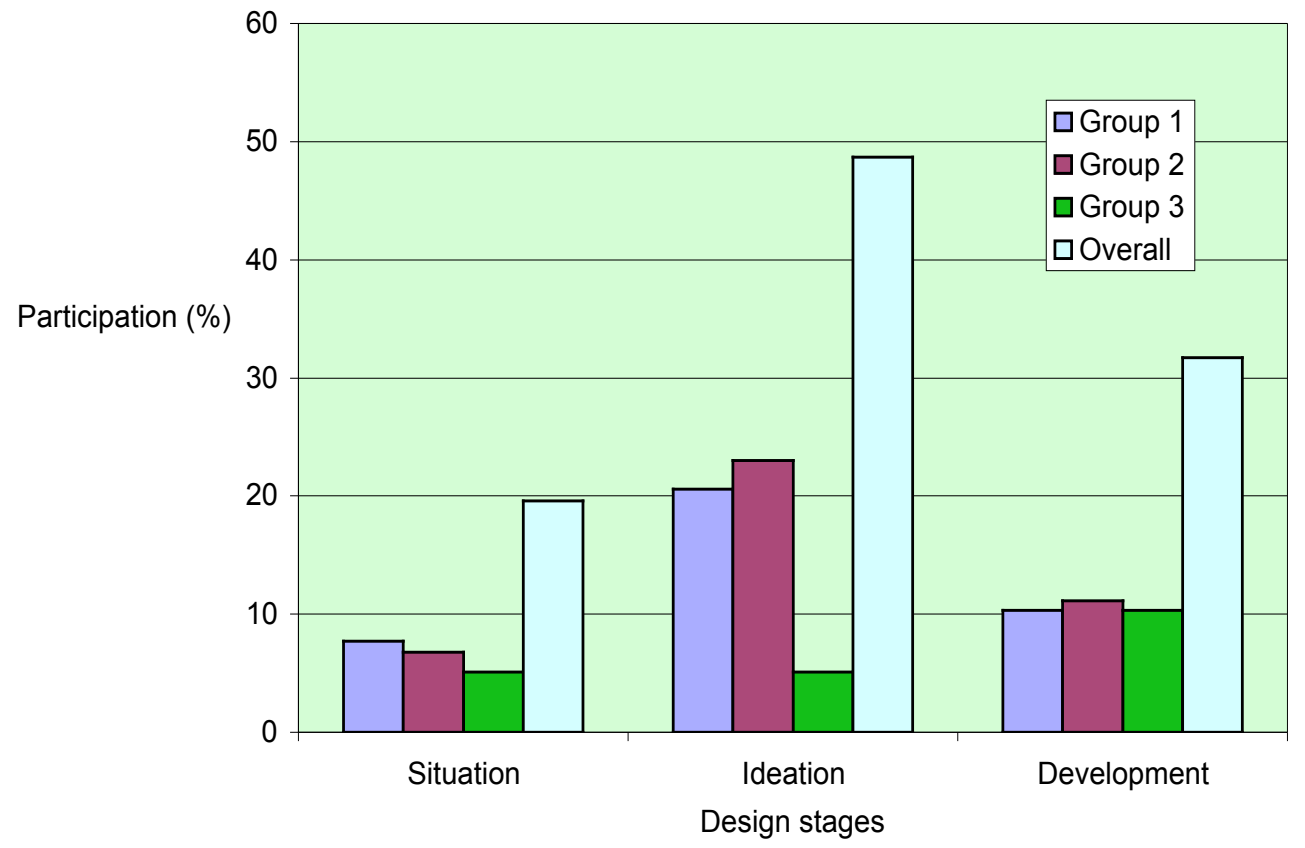

Figure 2: Graphical representation of group participation

Discussion of Ideation started after Situation. At Ideation, students from groups 1 and 2 increased their participation as they were actively engaged in commenting on design ideas and improving on them. Group 3, however, did not do likewise and their participation remained at the same level as at Situation. The students in group 3 might have felt uncomfortable participating in the online environment, preferring face to face discussion instead. There could also be the problem of students' inability to work together as a team. More attention could have been given to this project group during the forum discussion.

At Development, participation from groups 1 and 2 decreased while group 3 increased. It has to be pointed out that there was a lapse of about four months between the time the discussion forum ended at Ideation and restarted at Development. This long break in discussion was due to the mid-year examination followed by the long school vacation. This interruption could have changed the group dynamics and altered the participation pattern of the three groups.

\section{Students' cognitive levels displayed in information processing}

Quantitative measures of the cognitive levels of information processing by each of the three project groups at each stage of the design process are summarised in Table 6. These are based on the number of student posted messages analysed as cognitive 
dialogue. Cognitive dialogue refers to texts located within the postings of an asynchronous discussion forum that are indicative of learners' cognitive skills and strategies while engaged in a learning process (Henri, 1992; Henri \& Rigault, 1996), such as analysing, inferencing, judging, and synthesising. These messages are then further identified as surface or in depth levels of processing.

Table 6: Cognitive levels of processing

\begin{tabular}{|c|c|c|c|c|c|c|c|c|}
\cline { 2 - 8 } Group & \multicolumn{9}{|c|}{ No. of messages (\%) } & \multicolumn{2}{c|}{ Overall } \\
\cline { 2 - 8 } & \multicolumn{2}{|c|}{ Situation } & \multicolumn{2}{|c|}{ Ideation } & \multicolumn{2}{c|}{ Development } & \multicolumn{2}{c|}{} \\
\cline { 2 - 8 } & Surface & In depth & Surface & In depth & Surface & In depth & Surface & In depth \\
\hline 1 & $3(2.5)$ & $6(5.1)$ & $12(10.2)$ & $12(10.2)$ & $5(4.3)$ & $7(6.1)$ & $20(17.0)$ & $25(21.4)$ \\
\hline 2 & $0(0)$ & $8(6.8)$ & $7(6.1)$ & $20(17.1)$ & $5(4.3)$ & $8(6.8)$ & $12(10.3)$ & $36(30.7)$ \\
\hline 3 & $2(1.7)$ & $4(3.4)$ & $2(1.7)$ & $4(3.4)$ & $8(6.8)$ & $4(3.4)$ & $12(10.3)$ & $12(10.3)$ \\
\hline Overall & $5(4.2)$ & $18(15.3)$ & $21(18.0)$ & $36(30.7)$ & $18(15.4)$ & $19(16.3)$ & $44(37.6)$ & $73(62.4)$ \\
\hline
\end{tabular}

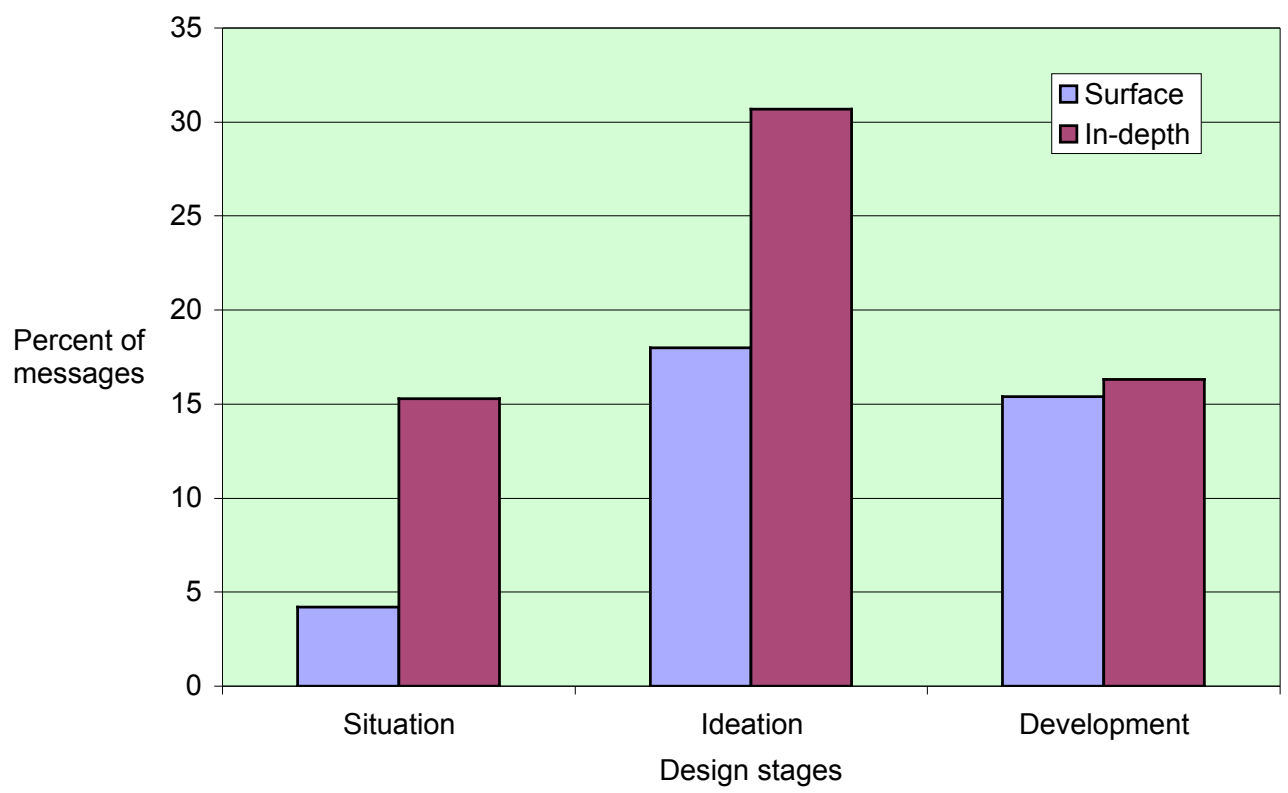

Figure 3: Graphical representation of cognitive levels of processing

In the D\&T learning context, surface level processing includes factors such as making judgments without justification, stating one's ideas or opinions that had already been stated, repeating what has been said, and asking irrelevant questions. On the other hand, in depth processing was apparent when one links facts and ideas, offers new elements of information, discusses advantages and disadvantages of a situation, and makes judgments that are supported by examples and/or justification.

An example of a forum message with surface level processing:

I think this is a good design but I think it can be improve by adding a refill container.

This student has suggested adding a refill container without giving any justification or explanation. 
An example of a forum message with in depth processing:

I think maybe by changing stainless steel to rubber-made cushions handles might be even more effective. It can ease the uncomfort of your hand and also not scald your hand when spill.

This student has suggested changing the handles from stainless steel to rubber by explaining that the change would ease discomfort on thands and prevent scalding.

The graphical representation of the overall cognitive levels of processing at each stage of the design process is shown in Figure 3. In depth level of processing is found to be higher than surface level of processing at every stage of the design process. The difference between these two levels of processing is more prominent at Situation and Ideation, but is marginal at Development. At the Situation stage, students' tasks were mainly to identify user needs and consider design factors that could affect the design of the product. Most of them were able to post relevant messages with justifications made. The design situation given to the students at this stage could have contributed to the relatively high in depth level of processing $(15.3 \%)$. The design situation might have been too simple and direct that it enabled students to justify what they have posted without much difficulty.

At the Ideation stage, the number of messages posted was the highest among the three stages. Students increased their postings as they were actively engaged in commenting on design ideas and improving on them. In depth level of processing $(30.7 \%)$ outnumbered surface level of processing (18\%). Most of the students were able to give comments about the design ideas and point out faults in the designs, giving explanations for doing so. They were also able to propose suggestions for improvements with justifications. At the Development stage, the difference between in depth level of processing (16.3\%) and surface level of processing (15.4\%) becomes marginal. At this stage, the students' main task was to consider design factors or development details for the making of the product. Many of the messages simply stated the choice of development details without giving any explanation. For example, they have indicated the choice of a particular joining method without providing any reason. This could be due to their lack of subject content knowledge which prevented them from making comparisons between different methods of joining.

\section{Survey results}

Survey statements with responses above 50\% for "Agree" or "Disagree" scales are highlighted here (see Appendix 1 for the overall response). In their perception of learning from online discussion, more than half of the students agreed that online discussion improved communication skills (53\%), provided useful social interaction $(53 \%)$, a great chance to share opinions with other participants $(73 \%)$ and was useful to learning $(53 \%)$. In the area of motivation and enjoyment, $60 \%$ of the students agreed that they enjoyed online discussion more than traditional methods of learning and 53\% of them disagreed that online discussion is a waste of time.

\section{Conclusions}

Out of the total of 117 messages posted by students, 23 were at the Situation stage, only $19.7 \%$. Their contributions to the forum were mainly individual notes and interaction among them was not evident as the messages were mainly in direct response to the teacher's posting. In this context, interaction refers to the students' 
build on messages in the form of follow up questions or clarification of peers' ideas. Perhaps they are still in the mindset of the teacher centred classroom, where teachers' posting requires their responses only. In terms of the learning task, perhaps the teacher's use of a simple and direct design situation presented to students could have resulted in their direct responses to the design situation without needing to discuss with peers, and therefore there was no elaboration and clarification taking place.

Of the 117 student-posted messages, 57 (48.7\%) were at the Ideation stage. Six design ideas were generated using SCAMPER technique (a form of creative thinking skill taught as just in time learning in D\&T), one design idea was generated without evidence of this technique being used, and no design idea was generated using Triggers technique. The research on existing products that the students conducted at the Situation stage could have helped them to generate design ideas more easily with the SCAMPER technique. Of the 57 student posted messages at this stage, $46(80.7 \%)$ were communicated with scaffolds emerging from students' discussion with the intention of helping others improve on their design ideas. Overall, these scaffolds helped students to make a total of four $(7 \%)$ improvements to their design ideas. These improvements made were indeed refinements of students' previous ideas and they have made the designs better in terms of their functionality and feature descriptions.

Of the total of 117 student posted messages, $37(31.6 \%)$ were at the Development stage. Of the 37 student posted messages at this stage, $19(51.4 \%)$ were considerations of design factors. This was considered a high contribution to the forum compared to the previous forums in Situation and Ideation stages, and the active participation could imply that students have no problem considering the design details that were necessary for making the product. The simple design ideas generated by the students could have allowed this to happen. It was found that $15(40.5 \%)$ messages out of the total of 37 messages at this stage were scaffolds used by students to help other students improve on their development ideas. These 15 scaffolds, in comparison with the 46 scaffolds (found at the Ideation stage), showed clearly that the discussion towards improvement of ideas at this stage was not as varied as that found in the Ideation stage. Three improvements of ideas were made at this stage and these were found to be minor improvements, but an important indication of students' learning in this study.

In this study, the students' learning was examined from their participation across the D\&T stages. It was observed that the three groups of students started with low participation at Situation stage. Perhaps, as these students were new to the technology mediated learning environment, they were learning to participate and explore in the forum. Since there was no interaction among them, there was no opportunity for them to evaluate each others' ideas. However, most of the students were able to participate by posting relevant messages with justifications made. The design situation presented to the students at this stage might have also contributed to the relatively high in depth level of information processing $(15.3 \%)$ by the students. The reason could be that the design situation was simple for students to relate to and easy for them to justify without much difficulty.

At the Ideation stage, students from groups 1 and 2 showed an increase in their participation in comparison with group 3 as they posted their messages on design ideas and ways of improving them. Students showed an in depth level of processing $(30.7 \%)$ which outnumbered surface level processing $(18 \%)$. Most of the students were able to give comments about the design ideas, point out faults in the designs and give 
explanations for doing so. They were also able to propose suggestions for improvements with justifications. Group 3, however, did not do likewise and their participation remained at the same level as that at Situation stage. Perhaps group 3 needed to be monitored more vigilantly by the teacher-facilitator so that they would perform as a group in discussing ideas.

At the Development stage, the participation based on number of messages from groups 1 and 2 decreased, while group 3 increased. There was a lapse of about four months between the time the discussion forum ended at Ideation and restarted at Development, due to mid-year examinations which were followed by the long school vacation. This interruption could have changed the group dynamics and altered the participation pattern of the three groups. Nevertheless, there were evaluations of peers' posted ideas and relevant comments about the ideas made by students. The difference observed between the in depth level of processing $(16.3 \%)$ and surface level of processing (15.4\%) became marginal at this stage. Many of the messages simply stated the choice of development details without giving any explanation. For example, they have indicated the choice of a particular joining method in D\&T without providing any reason. This could be due to their lack of subject content knowledge about materials and processes which prevented them from making further comparisons between different methods of joining.

It is apparent that the technology-mediated environment has engaged students' learning in terms of higher order thinking, and developing critical and creative thinking skills in the design process, as shown in their posted messages in the forums. Teachers' design of learning task and facilitation in the technology mediated learning environment are important in bringing about active engagement of students in discussion at every stage of the D\&T design process. Comparing participation by the three groups of students, it was found that group 3 was different from the other two, in terms of its performance in the design process in all the forums. There is a need to take into consideration group dynamics in technology mediated learning environments for future implementation of activities. Students' participation and learning in the discussion forums involves skills like idea analysis and evaluation taking place collaboratively. Although higher order thinking through in depth levels of information processing has been evident in the discussions, students have to be taught thinking skills more adequately so that they can benefit from the learning both cognitively and socially.

It would be advisable for D\&T teachers who are planning to start technology mediated environments in their schools to think of a more complex or ill-defined design situation in order to enable more interaction and discussion to take place right from the beginning. Close monitoring may be necessary to ensure active participation from all students. The students' domain knowledge in D\&T is also critical in enhancing high order thinking in the discussions. In general, students' favourable responses in the survey was an indication that learning in such an environment would be enriching if it is well designed and facilitated.

\section{References}

Albacete, P. L. \& VanLehn, K. (2000a). The Conceptual Helper: An intelligent tutoring system for teaching fundamental physics concepts. Intelligent Tutoring Systems: 5th International Conference, Montreal, Canada. Gauthier, Frasson, VanLehn (eds), Berlin: Springer (Lecture Notes in Computer Science, 1839), 564-573. 
Albacete, P. L. \& VanLehn, K. (2000b). Evaluating the effectiveness of a cognitive tutor for fundamental physics concepts. In L. R. Gleitman \& A. K. Joshi (Eds.), Proceedings of the 22nd Annual Meeting of the Cognitive Science Society. Mahwah, NJ: Erlbaum. 25-30.

Anderson, T., Rourke, L., Archer, W. \& Garrison, R. (2001). Assessing teaching presence in computer conferencing transcripts. Journal of Asynchronous Learning Networks, 5(2). http:/ / www.aln.org/alnweb/journal/jaln-vol5issue2v2.htm

Bonk, C. J. \& Cunningham, D. J. (1998). Searching for learner-centred, constructivist, and sociocultural components of collaborative educational learning tools. In C. J. Bonk \& K. S. King (Eds.), Electronic collaborators: Learner-centered technologies for literacy, apprenticeship, and discourse (pp. 25-50). Mahwah, NJ: Erlbaum.

Brown, A. L. \& Campione, J. C. (1996). Psychological theory and the design of innovative learning environments: On procedures, principles, and systems. In L. Schauble \& R. Glaser (Eds.), Innovations in learning: New environments for education (pp. 289-325). Mahwah, NJ: Erlbaum.

D\&T Syllabus, MOE. (2006). Design E Technology Syllabus, Secondary, Special/Express/Normal (Academic). Curriculum Planning and Development Division. Ministry of Education, Singapore.

Dabbagh, N. \& Bannan-Ritland, B. (2004). Online learning: Concepts, strategies, and application. Upper Saddle River, NJ: Prentice Hall, Inc.

Entwistle, N. \& Waterston, S. (1988). Approaches to studying and levels of processing in university students. British Journal of Educational Psychology, 58, 258-265.

Henri, F. (1992). Computer conferencing and content analysis. In A. R. Kaye (Eds.), Collaborative learning through computer conferencing: The Najaden papers, (pp. 115-136). New York: Springer.

Henri, F. \& Rigault, C. R. (1996). Collaborative distance learning and computer conferencing. In T. T. Liao (Ed.) Advanced educational technology: Research issues and future potential, (pp. 45-76). Berlin: Springer-Verlag.

Hopperton, L. (1998). Computer conferencing and college education. The College Quarterly, 5(2). [viewed 27 Dec 2007, verified 25 Oct 2008] http: / / www.senecac.on.ca/ quarterly/1998vol05-num02-winter/hopperton.html

Jamaludin, A. \& Quek, C. L. (2006). Using asynchronous online discussions in primary school project work. Australasian Journal of Educational Technology, 22(1), 64-87. http: / / www.ascilite.org.au/ajet/ajet22/jamaludin.html

Jonassen, D. H. (1991). Objectivism vs. constructivism: Do we need a new philosophical paradigm shift? Educational Technology: Research \& Development, 39(3).

Jonassen, D. H. (1998). Technology as cognitive tools: Learners as designers. IT FORUM Paper 1. [viewed 28 Dec 2007, verified 25 Oct 2008] http: / / itech1.coe.uga.edu/itforum/ paper1/paper1.html

Jonassen, D. H. \& Kwon, H. I. (2001). Communication patterns in computer mediated versus face-to-face group problem solving. Educational Technology Research \& Development, 49(1), 3551.

Klemm, W. R. \& Snell, J. R. (1996). Enriching computer-mediated group learning by coupling constructivism with collaborative learning. Journal of Instructional Science and Technology, 1(2) http:/ / www.ascilite.org.au / ajet/e-jist/docs/vol1no2/article1.htm

Knowlton, D. S., Knowlton, H. M. \& Davis, C. (2000). The whys and hows of online discussions. Syllabus: New Directions in Educational Technology, 13(10), 54-58.

$\mathrm{Ng}$, S. L. C. \& Cheung, W. S. (2007). Comparing face to face, tutor led discussion and online discussion in the classroom. Australasian Journal of Educational Technology, 23(4), 455-469. http: / / www.ascilite.org.au/ajet/ajet23/ng.html

Piaget, J. (1970). The science of education and the psychology of the child. NY: Grossman. 
Palloff, R. M. \& Pratt, K. (1999). Building learning communities in cyberspace: Effective strategies for the online classroom. San Francisco: Jossey-Bass.

Palloff, R. M. \& Pratt, K. (2005). Collaborating online: Learning together in community. San Francisco: Jossey Bass.

Roehler, L. \& Cantlon, D. (1997). Scaffolding: A powerful tool in social constructivist classrooms. In K. Hogan \& M. Pressley (Eds.), Scaffolding student learning: Instructional approaches and issues. Cambridge, MA: Brookline Books.

van Jooligen, W. (1999). Cognitive tools for discovery learning. International Journal of Artificial Intelligence, 10, 385-397.

Vygotsky, L. S. (1962). Thought and language (Trans. E. Hamfnann \& G. Vakar) Cambridge, MA: MIT Press.

Wenger, E. (1998). Communities of practice: Learning, meaning, and identity. New York: Cambridge University.

\section{Appendix 1}

\section{D\&T student's perception of learning from online discussion in Knowledge Forum in 2007 ( $\mathrm{N}=15$ students)}

Instruction: Please tick one answer for each question.

Name:

Date:

\begin{tabular}{|c|c|c|c|c|}
\hline & Question & Agree & Not sure & $\begin{array}{l}\text { Dis- } \\
\text { agree }\end{array}$ \\
\hline \multirow{9}{*}{$\begin{array}{l}\text { Learning } \\
\text { from } \\
\text { online } \\
\text { discuss- } \\
\text { ion }\end{array}$} & 1. I learn a great deal from peers in the online discussion & $6(40 \%)$ & $9(60 \%)$ & \\
\hline & 2. Learning quality is improved by the online discussion & $6(40 \%)$ & $9(60 \%)$ & \\
\hline & 3. It improves my communication skills & $8(53 \%)$ & $7(47 \%)$ & \\
\hline & 4. Online discussion provides useful social interaction & $8(53 \%)$ & $7(47 \%)$ & \\
\hline & $\begin{array}{l}\text { 5. It is a great chance to share opinions among peers and } \\
\text { teacher }\end{array}$ & $11(73 \%)$ & $4(27 \%)$ & \\
\hline & 6. It broadens my knowledge & $5(33 \%)$ & $10(67 \%)$ & \\
\hline & 7. Online discussion is useful to my learning & $8(53 \%)$ & $7(47 \%)$ & \\
\hline & 8. Most peers' comments are not very valuable & $3(20 \%)$ & $8(53 \%)$ & $4(27 \%)$ \\
\hline & 9. Online discussion decreases my learning quality & $3(20 \%)$ & $5(33 \%)$ & $7(47 \%)$ \\
\hline \multirow{8}{*}{$\begin{array}{l}\text { Motiva- } \\
\text { tion and } \\
\text { enjoy- } \\
\text { ment }\end{array}$} & $\begin{array}{l}\text { 10. I have motivation to learn more with online } \\
\text { discussion }\end{array}$ & $3(20 \%)$ & $12(80 \%)$ & \\
\hline & 11. It makes me more interested in the subject & $5(33 \%)$ & $9(60 \%)$ & $1(7 \%)$ \\
\hline & 12. It motivates me to do my best & $6(40 \%)$ & $9(60 \%)$ & \\
\hline & 13. My learning interest is improved by online discussion & $5(33 \%)$ & $10(67 \%)$ & \\
\hline & $\begin{array}{l}\text { 14. I enjoy online discussion more than traditional } \\
\text { method of learning }\end{array}$ & $9(60 \%)$ & $3(20 \%)$ & $3(20 \%)$ \\
\hline & $\begin{array}{l}\text { 15. I enjoy sharing knowledge with peers in online } \\
\text { discussion }\end{array}$ & $7(47 \%)$ & $8(53 \%)$ & \\
\hline & 16. I like online discussion & $6(40 \%)$ & $8(53 \%)$ & $1(7 \%)$ \\
\hline & 17. Online discussion wastes my time & $1(7 \%)$ & $6(40 \%)$ & $8(53 \%)$ \\
\hline
\end{tabular}

Yeo Tiong Meng, Design \& Technology, Marsiling Secondary School, 12 Marsiling Road, Singapore 739110. Email: yeo_tiong_meng@moe.edu.sg

Quek Choon Lang, Learning Sciences \& Technologies, National Institute of Education, Nanyang Technological University, Nanyang Avenue, Singapore 639798.

Email: choonlang.quek@nie.edu.sg 